\title{
Adoption and use of social media in academic libraries in South Africa
}

\author{
Benford Rabatseta ${ }^{1}$, Jan R. Maluleka ${ }^{2}$ and Omwoyo Bosire Onyancha ${ }^{3}$ \\ brabatseta@gmail.com ORCID: 0000-0002-7698-2819 \\ maluljr@unisa.ac.za ORCID: 0000-0002-3760-8162 \\ onyanob@unisa.ac.za ORCID: 0000-0002-9232-4939
}

Received: 2 July 2020

Accepted: 18 May 2021

\begin{abstract}
The purpose of this study was to investigate the extent of adoption and use of social media for client support by academic libraries in South Africa. A survey and content analysis were concurrently used to obtain relevant data to achieve the objectives of the study. The target population comprised seventyeight library workers from twenty-six institutions, consisting of administrators of social media, librarians and IT technicians. A total of forty-eight respondents completed and returned the questionnaires, which were then analysed using descriptive statistics. Results revealed that a variety of social media platforms are available and used in most libraries in South Africa; the most common platforms are Facebook, Twitter, YouTube and blogs. The social media platforms are used to market library services, announce library news and improve service delivery. The information shared with the users relates to user information, library events and new services. Most libraries do not have policies and/or guidelines specific to the management of social media usage. Library workers associated many benefits with social media platforms, but diverse factors affect the adoption and use of social media in the libraries. The study makes several recommendations in relation to the adoption and use of social media in libraries and for further research in the subject domain.
\end{abstract}

Keywords: Libraries, social media, South Africa

\section{Introduction}

The emergence of Information and Communications Technologies (ICTs) has resulted in the permeation of specific ICTbased utilities and applications in all the spheres of human activity. As Mahmood and Richardson (2011: 368) noted, social media tools are quickly gaining attractiveness in all sectors of the economy and across all communities. Of the most popular and perhaps most-used ICT-based applications are social media platforms and/or technologies. While social media platforms are mostly used by individual users, organisations have, in recent times, moved to install their presence on social media. Social media, defined as any technology or application that facilitates interaction and collaboration between online users, creating a community that extends beyond an organisation (Kaplan and Haenlein 2016: 59), can be categorised into social networks or social-networking sites (Facebook and Linkedln), content-sharing sites (YouTube, SharePoint and Instagram) and blogs and microblogs (Twitter).

The use of social media is widespread, but relatively new in academic libraries. A scan of the published literature using Google Scholar situates the earliest studies on social media in academic libraries after 2005. Since then, the number of studies on the subject has grown remarkably. The studies have dealt with various aspects, including: the awareness of social media platforms (Kaur \& Manhas 2018, Pooja, Bhat \& Rao 2019), the types of social media (Xie \& Stevenson 2014, Collins \& Quan-Haase 2014, Ndlangamandla \& Chisenga 2016), the purpose or specific area of social media application in libraries (Tuten 2008, Ezeani \& Igwezi 2012, Chu \& Du 2013, Jain 2014, Ofili \& Emwanta 2014, Islam \& Habiba 2015), the impact of using social media in service provision or library performance (Clark \& Bacon 2018, Mishra \& Maharana 2019), and the integration of social media in library services (Ahenkorah-Marfo \& Akussah 2016, Nalubega 2016), among other aspects. The scholars mentioned above, among others, have noted that social media platforms are increasingly being introduced and used in academic libraries to enhance service delivery, especially in developed countries. This study seeks to explore the use of social media in South Africa, one of the countries that constitutes the continent of Africa which is populated by developing and technologically challenged countries.

1. Benford Rabatseta is Senior Librarian in Library and Information Services at the North-West University, South Africa

2. Jan R. Maluleka is Associate Professor, Department of Information Science, University of South Africa

3. Omwoyo Bosire Onyancha is Research Professor, Department of Information Science, University of South Africa 


\section{Problem statement}

The research problem for the current study can be summarised in three areas. Firstly, Eister (2015: 18) highlighted that the merging of universities in South Africa in 2004 posed huge challenges for libraries at higher education institutions. The culture of education and learning, as part of redressing institutional imbalances, also had an impact on the future of libraries in terms of their roles, responsibilities, resources, staffing and funding models. Consequently, libraries had to adapt to the new spaces in which their parent bodies operated. The manner of operation and service provision to a greater population of library users became an issue with which to deal in various libraries. Libraries had to be more innovative in the manner in which they served their users.

Secondly, the emergence of ICTs means that digital literacy had to be implemented at universities, specifically in their libraries, to offer students support when it came to media literacy, ICT literacy, digital scholarship, as well as communication and collaboration in an academic context (Emiri 2015). In addition, digital usage of resources gave libraries new platforms on which to organise educational programmes for users. These programmes were developed in the belief that they would enable students to participate in digital networks for learning, research and the use of digital devices in online environments, and to further participate in emerging academic and research practices in the digital environment. Students increasingly apply their digital literacy skills and competencies in the use of such web tools as Twitter, Facebook, YouTube, LibGuides and other social media tools which have greatly impacted the academic library environment (Padma \& Ramasamy 2014). Social media is now considered a valuable tool to be used by institutions to support research and as a part of the marketing tools used to communicate with students.

Thirdly, penetration of the internet (and its applications, including social media technologies) and ICTs in Africa is high at 53\% (Penard et al. 2015). As a result, advanced technologies, such as social media, have brought change in the way academic libraries communicate with users. Libraries serve users who are dynamic and technologically highly competent. The same clients access information through technologically driven platforms - the internet and its many applications. The internet, which has brought about free access to information, could possibly render libraries irrelevant, since the latter are competing with other information providers (Ebrary and Google) that are taking advantage of the varied types of information technologies, such as literacy software and virtual reference technologies, to serve information users. Academic libraries in South Africa, just like their counterparts elsewhere in the world, find themselves in the conundrum that characterises the current digital age; and it is therefore pertinent to examine the status of using ICT tools for service delivery.

\section{Purpose and objectives of the study}

The purpose of this study was to investigate the extent of adoption and use of social media for client support by academic libraries in South Africa. The study specifically sought to:

- identify the types of social media available and used in academic libraries in South Africa;

- determine the purpose for which social media is applied in academic libraries in South Africa;

- identify the benefits associated with the application of social media in academic libraries;

- $\quad$ assess the policies and/or guidelines for the integration and use of social media in academic libraries; and

- $\quad$ assess the intensity of social media used by academic libraries in South Africa.

\section{Research methodology}

This quantitative study utilised a survey design to investigate the adoption and use of social media platforms and technologies by academic libraries in South Africa. Bryman (2012) views a survey design as a cross-sectional design with which data can be gathered through a self-administered questionnaire at a specific point in time to obtain a collection of quantifiable data. The choice of survey design was influenced by the selected quantitative research approach and the nature of the data that were collected. The survey research design also enhanced the gathering of standardised information by using questionnaires across the target population, scattered across the country. Having said that, survey research has reliability and validity issues as a weakness. Often answers provided by respondents may lack honesty and some respondents may feel uncomfortable providing answers that present them in an unfavourable manner. In order to mitigate reliability and validity issues associated with questionnaires, the instrument was pre-tested with the assistance of a few participants and adjustments were made to improve the instrument. Furthermore, content analysis was used to examine policy documents as well as data obtained from the websites of academic libraries. The websites of the libraries under study were scanned to uncover social media icons that are available on the sites and verify the data from respondents.

The study targeted administrators of social media in various libraries, librarians and IT technicians. The library websites provided details of personnel who were the target for this study. The actual number of respondents from the twenty-six institutions totalled seventy-eight, which consisted of administrators of social media, librarians and IT technicians. Given that the population was small, sampling was not done as it is an accepted practice among scholars to include all participants 
in the study if the number is manageable. For example, Fox, Murray and Warm (2003) indicated that, for a small population of under 200, the general guideline is that there is no compelling reason to apply any sampling method. For this reason, the researchers opted to study the whole population. In total, seventy-eight online survey questionnaires were sent out to the twenty-six academic libraries in South Africa. A total of forty-eight respondents completed and returned the questionnaire, giving a response rate of $61 \%$. The response rate was deemed adequate to proceed with the analysis of the findings. Collected data were analysed using SPSS software, including statistical analysis and graphics, which enabled descriptive analysis. Graphs, tables and charts were used to survey the data gathered systematically. The study was conducted in compliance with the ethical principles set out by the University of South Africa's (UNISA) policy on research ethics (2012). Ethical clearance was obtained from UNISA before the study could be conducted and all ethical guidelines were adhered to.

\section{Results and discussion}

This section presents and discusses the findings in accordance with the objectives of the study.

\subsection{Types of social media available and used in academic libraries in South Africa}

In terms of the types of social media available and used in the libraries, the study found that the top four most-used social media platforms are Facebook, Twitter, YouTube and blogs (see Table 1). Other emerging social media platforms include WhatsApp, Skype, Dropbox, Instagram and Real Simple Syndication (RSS). Scanning the web pages of the twenty-six academic libraries, with the help of university home pages, to determine the usage of social media in academic libraries revealed that Facebook, Twitter, Instagram, YouTube, WhatsApp, blogs, RSS, Linkedln, Dropbox and Mxit are used in these libraries. The study revealed that Facebook is the most visible social media platform of the websites followed by Twitter. YouTube and blogs have joined the race and results show that they are the second-most used media after Facebook and Twitter. The findings obtained in this study concur with those of Ezeani and Igwezi (2012) and Collins and Quan-Haase (2014) who observed that Facebook and Twitter were the social media platforms most used by academic libraries. In the view of Ezumah (2013), Facebook, Twitter, Myspace and Linkedln are used mainly in academic libraries in the United States of America (USA). Similarly, the current study found that students preferred Facebook to other social media platforms. The reasons for the popularity of Facebook have been explained by Ezeani and Igwezi (2012) who maintained that it is a social media platform suitable to communicate with library users and deliver library services.

Table 1 Social media platforms available and used in the academic libraries $(\mathrm{N}=48)$

\begin{tabular}{lcc}
\hline Social media platforms & Response frequency & Not applicable \\
\hline Facebook & $40(83 \%)$ & $8(17 \%)$ \\
Twitter & $30(63 \%)$ & $18(37 \%)$ \\
Instagram & $7(15 \%)$ & $41(85 \%)$ \\
YouTube & $27(56 \%)$ & $21(44 \%)$ \\
WhatsApp & $11(23 \%)$ & $37(77 \%)$ \\
Skype & $11(23 \%)$ & $37(77 \%)$ \\
Blogs & $22(46 \%)$ & $26(54 \%)$ \\
RSS & $6(13 \%)$ & $42(87 \%)$ \\
Linkedln & $3(6 \%)$ & $45(94 \%)$ \\
Dropbox & $10(21 \%)$ & $38(79 \%)$ \\
Other & $2(4 \%)$ & $46(96 \%)$ \\
\hline
\end{tabular}

Regarding the frequency of use of social media in the surveyed libraries, the results in Table 2 show that the majority of respondents used Facebook frequently (several times a day), followed by Twitter and YouTube. Four (8\%) respondents used Facebook once a day and eleven (22\%) respondents indicated that YouTube is used once a month in most of the libraries with access to it. The results in Table 2 further reveal that Mxit, Linkedln, RSS, Skype, Dropbox and WhatsApp are not used as frequently as other social media platforms in academic libraries in South Africa. Social media platforms that are not applicable to some libraries, as indicated by respondents, were: Instagram (forty-two; 82\%), Mxit (forty-three; 89\%), RSS (forty-one; 86\%), and Dropbox and Linkedln (both thirty-nine; 82\%). Although academic libraries use a wide range of social media platforms, they are selective in their use, specifically Facebook, Twitter and WhatsApp which are used several times a day. 
Table 2 Frequency of using social media $(\mathrm{N}=48)$

\begin{tabular}{|c|c|c|c|c|c|c|}
\hline $\begin{array}{l}\text { Types of social } \\
\text { media }\end{array}$ & Never & $\begin{array}{c}\text { Several times a } \\
\text { day }\end{array}$ & Once a day & Once a week & Once a month & Not applicable \\
\hline Facebook & $1(2 \%)$ & $21(44 \%)$ & $4(8 \%)$ & $7(15 \%)$ & $6(12 \%)$ & $9(19 \%)$ \\
\hline Twitter & $3(6 \%)$ & $14(30 \%)$ & $3(6 \%)$ & $7(15 \%)$ & $4(8 \%)$ & 17 (35\%) \\
\hline Instagram & $4(8 \%)$ & $0(0 \%)$ & $1(2 \%)$ & $1(2 \%)$ & $0(0 \%)$ & 42 (82\%) \\
\hline YouTube & $2(4 \%)$ & $3(6 \%)$ & $6(13 \%)$ & $4(8 \%)$ & $11(23 \%)$ & $22(46 \%)$ \\
\hline WhatsApp & $5(10 \%)$ & $6(13 \%)$ & $0(0 \%)$ & $0(0 \%)$ & $3(6 \%)$ & 34 (71\%) \\
\hline Mxit & $5(10 \%)$ & $0(0 \%)$ & $0(0 \%)$ & $0(0 \%)$ & $0(0 \%)$ & 43 (90\%) \\
\hline Skype & $3(6 \%)$ & $1(2 \%)$ & $0(0 \%)$ & $3(6 \%)$ & $6(13 \%)$ & 35 (73\%) \\
\hline Linkedln & $5(10 \%)$ & $0(0 \%)$ & $0(0 \%)$ & $4(8 \%)$ & $0(0 \%)$ & $39(82 \%)$ \\
\hline RSS & $3(6 \%)$ & $3(6 \%)$ & $1(2 \%)$ & $0(0 \%)$ & $0(0 \%)$ & $41(86 \%)$ \\
\hline Dropbox & $3(6 \%)$ & $4(8 \%)$ & $0(0 \%)$ & $0(0 \%)$ & $2(4 \%)$ & 39 (82\%) \\
\hline
\end{tabular}

A follow-up question that was meant to gauge how long the libraries have been using different types of social media revealed that many academic libraries in South Africa have been using Facebook, Twitter, YouTube, WhatsApp, Skype, RSS and Linkedln for five years and longer (see Figure 1).

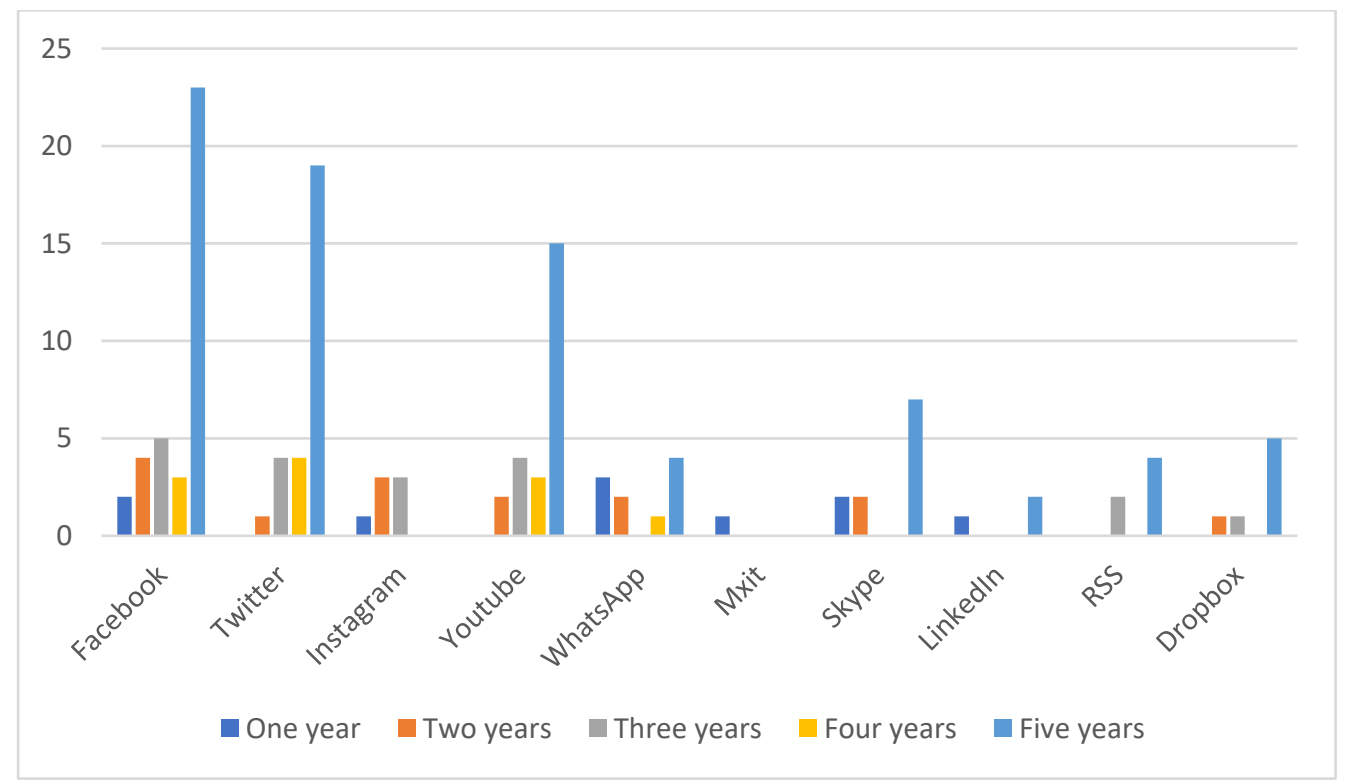

Figure 1 Length of time of social media application in the libraries $(\mathrm{N}=48)$

\subsection{Purpose for which social media is utilised in academic libraries}

In its examination of the purpose for which social media platforms are applied, the study revealed that most respondents reported that social media platforms in academic libraries are used to market the library, announce library news, improve library services, interact with users and alert them to new library materials. Table 3 reveals that a total of forty-six $(96 \%)$ respondents reported that social media is used to market the library; forty-four (92\%) use social media to announce library news; thirty-nine $(81 \%)$ to improve library services; thirty-seven $(77 \%)$ to introduce new library material and thirty $(63 \%)$ to build relationships with internal and external stakeholders. This activity is followed closely by twenty-five (52\%) respondents who stated that their libraries use social media to manage the library brand. Fourteen $(25 \%)$ respondents indicated that the library networks with other libraries through social media, while twelve $(25 \%)$ respondents said that the library uses social media to increase the library collection. Four (8\%) respondents indicated that their library uses social media to promote training opportunities and to encourage other libraries to adopt social media as a communication tool to market the library's resources, engage with students, build relationships and inform users of library news and new developments in the library.

Social media platforms could be valuable technological tools to improve services such as networking, marketing, communication and recruitment (Garber 2011). It is encouraging to note that academic libraries in South Africa are using social media platforms to improve library services and to interact with users. The use of social media in libraries can boost library visibility and increase its importance to its users. A study by Chu and Du (2013) pointed out that social media provides a way of information dissemination that inspires two-way communication between libraries and the user. While promotion 
of service is merely a one-way communication, social media tools include the capacity to provide two-way communication (Nguyen 2015). Rodgers (2009) argued that it is becoming the norm for academic libraries in the USA to use social media platforms to promote library services. Makori (2011) added that social media platforms help academic libraries to alert users to new library materials. The study by Collins and Quan-Haase (2014) noted that libraries are using social media to distribute information to platforms with which library users are familiar and they further mentioned that social media tools are widely used by academic libraries as a vehicle to provide information. A number of previous studies have mentioned that academic libraries are progressively using social media platforms to promote their services to library users (Ayu \& Abrizah 2011, Taylor \& Francis 2014)

Table 3 Purpose for using social media in academic libraries $(\mathrm{N}=48)$

\begin{tabular}{lcc}
\hline Purpose & Response frequency & Not applicable \\
\hline Improve library service delivery & $39(81 \%)$ & $9(19 \%)$ \\
Marketing the library & $46(96 \%)$ & $2(4 \%)$ \\
Manage library brand & $25(52 \%)$ & $23(48 \%)$ \\
Build library collection & $12(25 \%)$ & $36(75 \%)$ \\
Build relationships with internal and external stakeholders & $30(62 \%)$ & $18(38.5 \%)$ \\
Announce library news & $44(92 \%)$ & $4(8 \%)$ \\
Reference services & $18(38 \%)$ & $30(62 \%)$ \\
Network with other libraries & $14(29 \%)$ & $34(71 \%)$ \\
Alert users to new library material & $34(71 \%)$ & $14(29 \%)$ \\
Interact with users & $37(77 \%)$ & $11(23 \%)$ \\
Other & $4(8 \%)$ & $44(92 \%)$ \\
\hline
\end{tabular}

Fewer respondents indicated that social media is used in academic libraries to build relationships with internal and external stakeholders, manage the library brand, provide reference services, network with other libraries and build the library's collection. Mahmood and Richardson (2011) maintained that social media in academic libraries could be used to build relationships with stakeholders and manage the library brand. The studies of Kwanya, Stilwell and Underwood (2015) agreed that social media in academic libraries is used to facilitate reference services and network with other libraries. The majority of academic libraries surveyed in South Africa are using social media tools to communicate with one another and this indicates that they have adopted social media to build relationships with stakeholders as they manage the library brand.

In terms of the type of information shared with patrons using social media, Table 4 shows that forty-five (94\%) respondents shared library news with their users, while forty-five (94\%) indicated that they share library events with their users on social media. A total of thirty-eight $(79 \%)$ stated that they share new services that are available in their libraries with their users, while twenty-nine $(60 \%)$ agreed that they share new resources on the platforms to keep their users informed of new resources in their libraries. Twenty-two respondents $(46 \%)$ indicated that they share university news and sixteen $(33 \%)$ share faculty news on their library social media platforms. Five (10\%) respondents stated that they share other items like fun facts, posts of students in the library, research articles, and national and international trends. Some also specified that they share news from library and information associations such as the Library and Information Association of South Africa (LIASA), African Library and Information Associations and Institutions (AfLIA) and International Federation of Library Associations and Institutions (IFLA).

Table 4 Information shared with users through social media ( $N=48)$

\begin{tabular}{lcc}
\hline & Response frequency & Not applicable/unsure \\
\hline Library news & $45(94 \%)$ & $3(6 \%)$ \\
Library events & $45(94 \%)$ & $3(6 \%)$ \\
New resources & $29(60 \%)$ & $19(40 \%)$ \\
New services & $38(79 \%)$ & $10(21 \%)$ \\
University news & $22(46 \%)$ & $26(54 \%)$ \\
Faculty-related information & $16(33 \%)$ & $32(67 \%)$ \\
Other & $5(10 \%)$ & $43(90 \%)$ \\
\hline
\end{tabular}




\subsection{Factors influencing the use of social media in academic libraries in South Africa}

The respondents were requested to indicate the extent to which certain factors influenced academic libraries to make use of social media. Table 5 summarises the findings in which twenty $(42 \%)$ respondents indicated that their libraries were influenced by the marketing and advocacy policies in some way and eleven (23\%) indicated they were influenced to a great extent. Other factors that influenced the respondents, to a great extent, to use social media platforms are: internet access (35\%), marketing and advocacy policies (23\%), management support (21\%), and institutional policies, cooperation of staff with clients and community support which were each selected by $17 \%$ of the respondents.

Table 5 Factors influencing the use of social media in academic libraries $(\mathrm{N}=48)$

\begin{tabular}{|c|c|c|c|c|c|c|}
\hline Factors & $\begin{array}{c}\text { To a great } \\
\text { extent }\end{array}$ & Somewhat & Very little & Not at all & Do not know & Not applicable \\
\hline Cooperation of staff with clients & $14(29 \%)$ & $11(23 \%)$ & $6(13 \%)$ & $3(6 \%)$ & $4(8 \%)$ & $10(21 \%)$ \\
\hline User demand & $7(15 \%)$ & $12(25 \%)$ & $9(19 \%)$ & $5(10 \%)$ & $5(10 \%)$ & $10(21 \%)$ \\
\hline Management support & $10(21 \%)$ & $11(23 \%)$ & $15(31 \%)$ & $2(4 \%)$ & $4(8 \%)$ & $6(12 \%)$ \\
\hline Institutional policies & $8(17 \%)$ & $12(25 \%)$ & $8(17 \%)$ & $5(10 \%)$ & $4(8 \%)$ & $11(23 \%)$ \\
\hline Cooperation of staff with clients & $8(17 \%)$ & $11(23 \%)$ & $9(19 \%)$ & $3(6 \%)$ & $4(8 \%)$ & $13(27 \%)$ \\
\hline Social media policies & $5(10 \%)$ & $14(29 \%)$ & $3(6 \%)$ & $10(21 \%)$ & $5(10 \%)$ & $11(23 \%)$ \\
\hline Internet access & $17(35 \%)$ & $7(15 \%)$ & $8(17 \%)$ & $1(2 \%)$ & $4(8 \%)$ & $11(23 \%)$ \\
\hline Community support & $8(17 \%)$ & $6(13 \%)$ & $9(19 \%)$ & $8(17 \%)$ & $5(10 \%)$ & $12(25 \%)$ \\
\hline Library association policies & $5(10 \%)$ & $9(19 \%)$ & $4(8 \%)$ & $11(23 \%)$ & $8(17 \%)$ & $11(23 \%)$ \\
\hline
\end{tabular}

As a way of triangulation, a question was posed to determine the factors that might lead to the non-use of social media platforms in academic libraries in South Africa. Table 6 reveals that twenty-one (44\%) respondents agreed that restrictive institutional policies may contribute to the non-use of social media at their libraries to a great extent. Seventeen (35\%) respondents believed that poor internet access was an important determining factor for non-use, while fourteen (29\%) thought the same of the unavailability of social media policies. Twelve $(25 \%)$ were greatly discouraged by the unwillingness of staff to change, while eleven (23\%) saw lack of support from management and lack of cooperation of staff respectively as being important factors determining non-use of social media.

Table 6 Factors that influenced non-use of social media $(\mathrm{N}=48)$

\begin{tabular}{|c|c|c|c|c|c|c|}
\hline Factors & $\begin{array}{c}\text { To a great } \\
\text { extent }\end{array}$ & $\begin{array}{c}\text { To a moderate } \\
\text { extent }\end{array}$ & $\begin{array}{l}\text { To some } \\
\text { extent }\end{array}$ & $\begin{array}{l}\text { To a small } \\
\text { extent }\end{array}$ & $\begin{array}{l}\text { To the least } \\
\text { extent }\end{array}$ & Not applicable \\
\hline Lack of staff cooperation & $11(23 \%)$ & $9(19 \%)$ & $9(19 \%)$ & $8(17 \%)$ & $8(17 \%)$ & $3(6 \%)$ \\
\hline $\begin{array}{l}\text { Lack of support from } \\
\text { management }\end{array}$ & $11(23 \%)$ & $6(13 \%)$ & $9(19 \%)$ & $11(23 \%)$ & $9(19 \%)$ & $2(4 \%)$ \\
\hline Poor internet access & $17(35 \%)$ & $3(6 \%)$ & $5(10 \%)$ & $5(10 \%)$ & $12(25 \%)$ & $6(13 \%)$ \\
\hline $\begin{array}{l}\text { Staff unwillingness to } \\
\text { change }\end{array}$ & $12(25 \%)$ & $7(15 \%)$ & $10(21 \%)$ & $8(17 \%)$ & $7(15 \%)$ & $4(8 \%)$ \\
\hline $\begin{array}{l}\text { Unavailability of social } \\
\text { media policies }\end{array}$ & $14(29 \%)$ & $1(2 \%)$ & $16(33 \%)$ & $9(19 \%)$ & $3(6 \%)$ & $5(10 \%)$ \\
\hline $\begin{array}{l}\text { Restrictive institutional } \\
\text { policies }\end{array}$ & $21(44 \%)$ & $4(8 \%)$ & $6(13 \%)$ & $8(17 \%)$ & $5(10 \%)$ & $4(8 \%)$ \\
\hline
\end{tabular}

It is illustrative that there are several factors that influence the use of social media in academic libraries in South Africa. The findings in Table 5 concur with the studies of Burgert, Nann and Sterling (2014) who highlighted that internet access and cooperation among staff and clients greatly influence the use of social media. Burgert, Nann and Sterling (2014) and Arif and Mahmood (2012) further highlighted that the opinion of library users is far more important in influencing libraries to adopt and use social media. This study further revealed that the willingness of staff to change encouraged libraries to use social media. This is in line with a study conducted by Arif and Mahmood (2012) who maintained that individuals must use the technological tools that are available and useful to improve their daily employment. 
On the one hand, the main factors that discourage or may discourage librarians from using social media are restrictive institutional policies and poor internet access. Onyaoku, Orakpor and Ezejiofor (2012) commented on poor internet connection as a limiting factor to use social media in academic libraries. Moreover, the unavailability of social media policies is seen as a discouragement to libraries to use social media platforms. Similarly, Kooy and Steiner (2010) submitted that the absence of social media policies in libraries might lead to users abusing the platform. This study further indicated that a lack of management support and staff cooperation play a role in discouraging libraries to adopt social media. These results are in line with the findings of Chu and $\mathrm{Du}$ (2013) who argued that libraries lack the time to make use of social media effectively. The effectiveness of social media in academic libraries depends on the initiative by library staff and the type of technology they use. The study confirms the views of Hosseini and Hashempour (2012) who indicated that the unwillingness of staff to change might contribute as a factor inhibiting the use of social media.

\subsection{Benefits associated with the use of social media in academic libraries}

Table 7 shows that there are many benefits of using social media. The findings reveal that academic libraries benefitted from social media in that the platforms promote library services, increase communication with other departments, help libraries to gather feedback to improve user services, help to build connections and reputation broadly, result in better user satisfaction, improve brand loyalty with users, bring about cost-effective practices and gain marketplace insight. Ntaka (2017) observed that the main benefit associated with social media was that it aided libraries to meet students' academic needs and to engage with them and encourage them to use libraries. Other benefits associated with the application of social media in academic libraries include increasing brand awareness, building communication and reputation, gathering of feedback to improve users' service, enhancing satisfaction, improving brand loyalty, gaining marketplace insight and being cost-effective.

Table 7 Benefits of using social media in libraries $(\mathrm{N}=48)$

\begin{tabular}{|c|c|c|c|c|c|c|}
\hline Benefit of using social media & $\begin{array}{c}\text { Most } \\
\text { beneficial }\end{array}$ & $\begin{array}{c}\text { Fairly } \\
\text { beneficial }\end{array}$ & Beneficial & $\begin{array}{c}\text { Slightly } \\
\text { beneficial }\end{array}$ & $\begin{array}{c}\text { Least } \\
\text { beneficial }\end{array}$ & $\begin{array}{c}\text { Not } \\
\text { applicable }\end{array}$ \\
\hline Promotes library services & $30(63 \%)$ & $9(19 \%)$ & $2(4 \%)$ & $1(2 \%)$ & $3(6 \%)$ & $3(6 \%)$ \\
\hline Increases interaction and engagement with library users & $28(58 \%)$ & $3(6 \%)$ & $9(19 \%)$ & $4(8 \%)$ & $2(4 \%)$ & $2(4 \%)$ \\
\hline Increases communication with other departments & $13(27 \%)$ & $4(8 \%)$ & $14(29 \%)$ & $8(17 \%)$ & $4(8 \%)$ & $5(10 \%)$ \\
\hline Gathers feedback to improve users' services & $16(33 \%)$ & $10(21 \%)$ & $14(29 \%)$ & $3(6 \%)$ & $2(4 \%)$ & $3(6 \%)$ \\
\hline Helps to broadly build connection and reputation & $19(40 \%)$ & $7(15 \%)$ & $9(19 \%)$ & $9(19 \%)$ & $1(2 \%)$ & $3(6 \%)$ \\
\hline Better user satisfaction & $11(23 \%)$ & $12(25 \%)$ & $17(35 \%)$ & $4(8 \%)$ & $1(2 \%)$ & $3(6 \%)$ \\
\hline Improves brand loyalty with users & $11(23 \%)$ & $12(25 \%)$ & $15(31 \%)$ & $4(8 \%)$ & $3(6 \%)$ & $3(6 \%)$ \\
\hline Brings about cost-effective & $8(17 \%)$ & $10(21 \%)$ & $13(27 \%)$ & $6(13 \%)$ & $7(14 \%)$ & $6(13 \%)$ \\
\hline Gains marketplace insights & $10(21 \%)$ & $15(31 \%)$ & $7(15 \%)$ & $9(19 \%)$ & $4(8 \%)$ & $3(6 \%)$ \\
\hline
\end{tabular}

The study by Collins and Quan-Haase (2012) upheld the view that the application of social media in academic libraries improves the level of communication and reputation. Similar sentiments were voiced by Breeding (2007) who affirmed that social media could be used to gather feedback in order to improve the quality of service received by the user. In the view of Farkas (2007) and Ayiah and Kumah (2011), the application of social media in academic libraries increased user satisfaction and thereby improved brand loyalty. Moreover, these findings concur with those of Kumar (2015) who maintained that the application of social media in academic libraries leads to effective storage and dissemination of information, development of users' practical skills, exchange of information between library staff and the user, and a gain in marketplace insight.

\subsection{Policies guiding the use of social media}

Firstly, the respondents were asked to indicate if their library had a policy guiding the use of social media for different groups of users. The results in Table 8 show that the majority of libraries, totalling thirty-nine (81\%), do not have a policy on social media platforms for the general public. A total of thirty-one $(65 \%)$ respondents indicated that they do not have a guiding policy on social media for students, twenty-eight (58\%) respondents indicated that they have no policy guiding the use of social media for faculties, while fifteen (31\%) indicated that they do have a social media policy for faculties. Twenty-eight $(58 \%)$ respondents indicated that they do not have a social media policy for support staff and fourteen (29\%) indicated that they do have a policy on social media guiding support staff. Twenty-three $(48 \%)$ of the respondents indicated that their 
libraries do not have a social media policy guiding library staff, while twenty-one (44\%) indicated that they have a social media policy guiding library staff to use social media. The results also show that thirty-one (65\%) respondents indicated that their libraries do not have a policy guiding students and twelve (25\%) indicated that their libraries do have such a policy. It is, therefore, illustrative that more academic libraries in South Africa do not have policy documents guiding them on the use of social media tools than those who do. Kooy and Steiner (2010) made similar observations whereby they noted that academic libraries in southern Africa preferred to formulate social media policies as the need arose.

Table 8 Library policy guiding the use of social media by category of users $(N=48)$

\begin{tabular}{lcccccc}
\hline $\begin{array}{l}\text { Existence of policy guiding use } \\
\text { of social media }\end{array}$ & Library staff & Students & Faculties & $\begin{array}{c}\text { Academic } \\
\text { Staff }\end{array}$ & $\begin{array}{c}\text { Support } \\
\text { staff }\end{array}$ & Public \\
\hline Yes & $21(44 \%)$ & $12(25 \%)$ & $15(31 \%)$ & $15(31 \%)$ & $14(29 \%)$ & $2(4 \%)$ \\
No & $23(48 \%)$ & $31(65 \%)$ & $28(58 \%)$ & $27(56 \%)$ & $28(58 \%)$ & $39(81 \%)$ \\
No answer & $4(8 \%)$ & $5(10 \%)$ & $5(10 \%)$ & $6(13 \%)$ & $6(13 \%)$ & $7(15 \%)$ \\
\hline
\end{tabular}

Secondly, when prodded on the plans or intentions of libraries to introduce policies on the use of social media in the libraries, seventeen (59\%) of the respondents who indicated that their libraries have not developed a social media policy said that their libraries intended to introduce a policy; while twelve $(41 \%)$ of respondents indicated that their libraries do not have plans to introduce a social media policy for any groups. The latter might reflect a concern that the non-availability of policies or guidelines on using social media may result in users taking advantage of and abusing the platforms (Aras and Çolaklar 2015). It is however gratifying to note that a large number of respondents indicated that their libraries intend to introduce social media policies in line with Kooy and Steiner's (2010) recommendation. Academic libraries should adopt a social media policy to control the behaviour of users on their social media platforms in order to avoid any users' posts that would lead to a legal dispute (Rouse 2011). Rouse (2011) argued that academic libraries should formulate policies outlining appropriate and inappropriate content of posts on social media platforms, highlight the main purpose of these platforms and state that unacceptable behaviour by users on these platforms would not be tolerated.

\subsection{Assessing the use of social media platforms by academic libraries in South Africa}

Finally, the study sought to examine the intensity of use of social media by academic libraries in South Africa. When asked whether or not their libraries assessed the usage of social media platforms, twenty-two (46\%) respondents indicated that their libraries do measure the use of social media, while fourteen (29\%) indicated that they do not measure the use of social media and twelve (25\%) are not sure if their libraries measure its use. Figure 2 shows these responses.

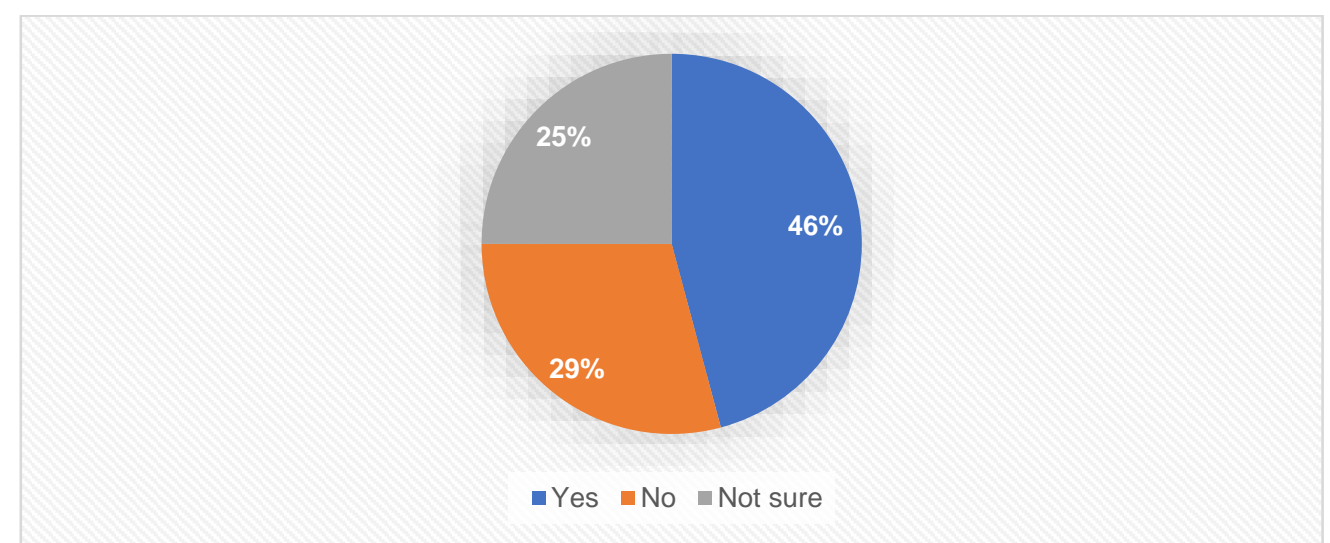

Figure 2 Whether or not libraries assessed the use of their social media platforms $(N=48)$

The respondents were then asked to indicate which tools they used to assess the usage of social media in their libraries. Sixteen (33\%) respondents indicated that they use free tools to measure the use of social media; while six (13\%) indicated that they use commercial and free tools (open source) to measure the use of social media in the libraries. The rest of the respondents, twenty-six (54\%), who did not indicate whether they used any tools to measure the usage of the platforms, included the respondents who had said that they do not measure the usage of the platforms in their libraries. When probed further on the specific tools that they use to measure the usage of the platforms, nine (19\%) respondents indicated that they use TweetDeck to monitor the use of social media; five (10\%) respondents use HootSuite and seven respondents (15\%) use Klout, Libguides stats, Facebook and Twitter. The use of an annual audit was also mentioned as a tool to monitor the use of social media platforms in some academic libraries. One concern was that there are libraries that do not measure the 
usage of social media and their librarians are not sure if their platforms are being monitored. This is not unique to South Africa since studies such as that of Geho and Dangelo (2012) found that, although there are tools and documents that show how far social media reaches clients, few libraries used these tools. Geho and Dangelo (2012) pointed out that Facebook Insights is a tool that is widely used to measure the usage of Facebook. The tool shows how many people viewed and shared media and can also provide the geographical location of pages viewed. Another example is Hootsuite which provides insight into when libraries are being monitored or have their posts shared. Geho and Dangelo (2012) further indicated that Hootsuite allows libraries to manage social media platforms in one place.

The respondents were further asked to indicate the types of metrics they use to assess the success of the social media platforms of libraries (Table 9). It was found that twenty-eight (58\%) libraries use the number of followers as a metric to measure success, while twenty-three $(48 \%)$ use the number of tweets and retweets for this purpose. The libraries of twenty $(42 \%)$ respondents use the number of visitors, seventeen (35\%) said that their libraries use registered members and thirteen $(27 \%)$ use audience feedback. Eleven $(23 \%)$ respondents indicated that their libraries employ the comments of users. It, therefore, follows that a variety of statistics do exist to monitor and assess the usage of social media platforms in academic libraries in South Africa. Griffin and Taylor (2013) highlighted some of these as: the number of posts and the results of likes, comments, followers, shares and number of fans/followers.

Table 9 Metrics $(\mathrm{N}=48)$

\begin{tabular}{lll}
\hline Metrics & No. of respondents & No selection \\
\hline Followers & $28(58 \%)$ & $20(42 \%)$ \\
Registered members & $17(35 \%)$ & $31(65 \%)$ \\
Tweets; retweets & $23(48 \%)$ & $25(52 \%)$ \\
Comments & $11(23 \%)$ & $37(77 \%)$ \\
Audience feedback & $13(27 \%)$ & $35(73 \%)$ \\
Visitors & $20(42 \%)$ & $28(58 \%)$ \\
None & $13(27 \%)$ & $35(73 \%)$ \\
\hline
\end{tabular}

When asked to rate the usefulness of the metrics listed in Table 10 to assess the usage of social media platforms in their libraries, thirty-one $(65 \%)$ respondents felt that the number of followers was a useful statistic, while the number of registered social media members was deemed useful by twenty-nine $(63 \%)$ respondents. The number of tweets and retweets was considered a useful statistic by twenty-eight (59\%) respondents while twenty $(41 \%)$ were of the opinion that tweets and retweets are either not useful or not applicable. Comments, audience feedback and visitors were thought to be useful by thirty $(63 \%)$, thirty-one $(65 \%)$ and twenty-five $(52 \%)$ respondents respectively. Therefore, in all the cases, the number of respondents who felt that the listed statistics or measures are useful to assess the social media platforms surpassed the number of respondents who thought otherwise. It was interesting to note that, despite the overlaps in some instances, for example in instances where a follower can also be a member or a visitor, the number of respondents who did not know whether or not the measures are useful for assessing social media usage was relatively high (if the number of those who did not make any selection of the options was to be taken into consideration). This group of library workers should be a concern to the library management, especially if they are actively involved in supporting patrons who use the library's social media platforms. It is in the interest of the library that all staff members are aware of the measures and indicators that can be used to gauge the quality of services offered in their libraries.

Table 10 Usefulness of statistics to assess usage of social media platforms $(\mathrm{N}=48)$

\begin{tabular}{lccccc}
\hline & Extremely useful & Useful & Not useful & Do not know & No selection \\
\hline Followers & $12(25 \%)$ & $19(40 \%)$ & $1(2 \%)$ & $5(10 \%)$ & $11(23 \%)$ \\
Registered members & $8(17 \%)$ & $21(44 \%)$ & $2(4 \%)$ & $5(10 \%)$ & $12(25 \%)$ \\
Tweets and retweets & $10(21 \%)$ & $18(38 \%)$ & $3(6 \%)$ & $4(8 \%)$ & $13(27 \%)$ \\
Comments & $12(25 \%)$ & $18(38 \%)$ & $2(4 \%)$ & $4(8 \%)$ & $12(25 \%)$ \\
Audience feedback & $8(17 \%)$ & $23(48 \%)$ & $1(2 \%)$ & $4(8 \%)$ & $12(25 \%)$ \\
Visitors & $10(21 \%)$ & $15(31 \%)$ & $2(4 \%)$ & $6(13 \%)$ & $15(31 \%)$ \\
\hline
\end{tabular}




\section{Conclusion and recommendations}

The study established that there was evidence of the adoption and use of social media by academic libraries in South Africa. Social media platforms such as Facebook, Twitter, YouTube and blogs were the most preferred platforms by academic libraries in South Africa. Among the most used social media platforms by academic libraries in South Africa, Facebook was the most popular platform. The results further revealed that these social media platforms are mainly used for marketing services rendered by these academic libraries. Furthermore, the results suggest that social media platforms are used to build relationships with internal and external stakeholders, to manage the library brand, for reference services and to network with other libraries. The study also revealed that using social media helped improve library services and increased interaction and engagement with library users. Other benefits associated with the application of social media in academic libraries include increasing brand awareness as well as building communication and reputation. The librarians, however, highlighted that restrictive institutional policies and poor internet connections hindered them from effectively using different social media platforms. The results suggest that most academic libraries in South Africa do not have policy documents guiding them on the use of social media tools. The lack of policy guidelines has affected how these platforms are used. The results suggest that academic libraries in South Africa are not maximising the use of social media. Most libraries are not even measuring their social media usage. A few that do measure social media usage make use of free tools, while some libraries use both commercial and free tools. As a result, the study could not determine the intensity of social media usage by academic libraries in South Africa.

The economic situation in South Africa forces every institution in every sector to do more with limited resources. The study, therefore, recommends that academic libraries maximise their use of social media platforms, which are mostly freely available and easy to use. Academic libraries should have social media accounts which are active, and they should employ a social media administrator who will take care of social media activities on a full-time basis. The study further recommends that academic libraries introduce social media policies that would guide library users and staff. In addition, academic libraries should take advantage of free tools that are available to measure the success of social media and provide quick links to social media platforms on library websites.

\section{Implications of the study}

Research findings must, to some extent, be connected to what people already know and write about or believe in relation to the topic in question (Leedy \& Ormord 2014). The findings of this study may go a long way in influencing policy and practice in the use of social media in libraries. The study will assist libraries in their adoption and use of social media as a form of communication platform with their users. The study will further assist in adding to the existing knowledge on the adoption and use of social media in libraries. Recommendations made by the study will be beneficial to all types of libraries.

\section{References}

Ahenkorah-Marfo, M. and Akussah, H. 2016. Being where the users are: readiness of academic librarians to satisfy information needs of users through social media. Library Review, 65(8/9): 549-563.

Aras, B.B. and Çolaklar, H. 2015. The role of social media in the promotion of university libraries. Journal of Library and Information Sciences, 3(2): 79-105

Arif, M. and Mahmood, K. 2012. The changing role of librarians in the digital world: adoption of Web 2.0 technologies by Pakistani librarians. The Electronic Library, 30(4): 469-479.

Ayiah, E.M. and Kumah, C.H. 2011. Social networking: a tool to use for effective service delivery to clients by African Libraries. Proceedings of the 77th IFLA General Conference and Assembly. 13-18 August 2011. San Juan, Puerto Rico.

Ayu, A.R. and Abrizah, A. 2011. Do you Facebook? Usage and applications of Facebook page among academic libraries in Malaysia. The International Information and Library Review, 43(4): 239-249

Breeding, M. 2007. Librarians face online social networks. Computers in Libraries, 27(8): 30-32

Burgert, L., Nann, A. and Sterling, L. 2014. Ventures in social media. Codex: The Journal of the Louisiana Chapter of the ACRL, 3(1): 21-44

Bryman, A. 2012. Social research methods. 4th ed. North Carolina: Oxford University Press

Chu, S.K.W. and Du, H.S. 2013. Social networking tools for academic libraries. Journal of Librarianship and Information Science, 45(1): 64-75.

Clark, M.N. and Bacon, S.D. 2018. Utilising social media to improve relationship quality: the case of the university library. International Journal of Electronic Customer Relationship Management, 11(4): 384-410.

Collins, G. and Quan-Haase, A. 2012. Social media used by Ontario university libraries: challenges and ethical considerations. Proceedings of the Annual Conference of CAIS. 31 May-2 June. Waterloo, Canada. DOI:10.29173/cais631.

Collins, G. and Quan-Haase, A. 2014. Are social media ubiquitous in academic libraries? A longitudinal study of adoption and usage patterns. Journal of Web Librarianship, 8(1): 48-68. 
Eister, K. 2015. Library sectors: academic and research libraries. In The state of the libraries in South Africa. Pretoria: Department of Arts and Culture. 18-19. [Online]. http://www.liasa-new.org.za/wp-content/uploads/2015/09/State-ofSA-libraries-2015.pdf (19 May 2018).

Emiri, O.T. 2015. Digital literacy skills among librarians in university libraries in the 21st century in Edo and Delta States, Nigeria. International Journal of Library and Information Services (IJLIS), 6(1). DOI: 10.4018/IJLIS.2017010103.

Ezeani, C.N. \& Igwezi, U. 2012. Using social media for dynamic library services delivery: the Nigerian experience. Library Philosophy and Practice (e-journal). 814. https://digitalcommons.unl.edu/libphilprac/814.

Ezumah, B.A. 2013. College students' use of social media: site preferences, uses and gratifications theory revisited. International Journal of Business and Social Science, 4(5).

Farkas, M. 2007. Technology in practice: going where patrons are. American Libraries, 38(4): 27.

Fox, J., Murray, C. and Warm, A. 2003. Conducting research using web-based questionnaires: practical methodological and ethical considerations. International Journal of Social Research Methodology, 6(2):167-180.

Garber, M.B. 2011. Social media policy on campus: a case study of the development and implementation of a social media policy for university administrators, faculty, and staff. PhD thesis. Mercer University.

Geho, P.R. and Dangelo, J. 2012. The evolution of social media as a marketing tool for entrepreneurs. The Entrepreneurial Executive, 17: 61.

Griffin, M. and Taylor, T.I. 2013. Of fans, friends, and followers: methods for assessing social media outreach in special collections repositories. Journal of Web Librarianship, 7(3): 255-271.

Hosseini, E. and Hashempour, L. 2012. The status of librarians' knowledge sharing by the usage of Web 2.0 tools: a case study of central libraries of Tabriz governmental universities. Communications in Computer and Information Science, 317: 128-137.

Islam, M.M. and Habiba, U. 2015. Use of social media in marketing of library and information services in Bangladesh DESIDOC. Journal of Library and Information Technology, 35(4): 299-303.

Jain, P. 2014. Application of social media in marketing library and information services: a global perspective. International Journal of Academic Research and Reflection, 2(2): 25.

Kaplan, A.M. and Haenlein, M. 2016. Higher education and the digital revolution: about MOOCs, SPOCs, social media, and the cookie monster. Business Horizons, 59: 441-450.

Kaur, S. and Manhas, R. 2018. Awareness, knowledge, attitude and use of social media among librarians and the libraries of medical colleges of Punjab: a study. IP: Indian Journal of Library Science and Information Technology, 3(2): 70-71.

Kooy, B. and Steiner, K. 2010. Protection, not barriers: using social software policies to guide and safeguard students and employees. Reference and User Services Quarterly, 50(1): 59-71.

Kumar, C.R. 2015. Social network impact on academic libraries in technology era. International Journal of Library and Information Studies, 5(3): 101-108.

Kwanya, T., Stilwell, C. \& Underwood, P.G. 2015. A mediated marketplace: effective knowledge sharing and learning among local civil society organizations in developing countries. Information Development, 31(5): 461-472.

Leedy P.D. and Ormord, J.E. 2014. Practical research and design. 10th ed. New Jersey: Pearson Education, Inc.

Mahmood, K. and Richardson, J.V. 2011. Adoption of Web 2.0 in US academic libraries: a survey of ARL library websites. Program, 45(4): 365-375.

Makori, E.O. 2011. Bridging the information gap with the patrons in university libraries in Africa: the case for investments in Web 2.0 systems. Library Review, 61(4): 340-350.

Mishra, C \& Maharana, B. 2019. Impact of social media on academic business school libraries in India: an empirical study. Library Philosophy and Practice (e-journal). 2871. https://digitalcommons.unl.edu/libphilprac/2871.

Nalubega, R. 2016. Integration of social media tools in academic libraries: Makerere University students' perspective. Proceedings of the $22^{\text {nd }}$ Standing Conference of Eastern, Central and Southern Africa Library and Information Associations - SCECSAL XXII: Digital Transformation and the Changing Role of Libraries and Information Centres in the Sustainable Development of Africa. Mbabane: Swaziland Library and Information Association. 547-555. [Online]. https://www.scecsal.org/publications/papers2016/054_nalubega_2016.pdf (18 May 2020).

Ndlangamandla, K. and Chisenga J. 2016. Social media in university libraries in the SADC Region. Proceedings of the $22^{\text {nd }}$ Standing Conference of Eastern, Central and Southern Africa Library and Information Associations - SCECSAL XXII: Digital Transformation and the Changing Role of Libraries and Information Centres in the Sustainable Development of Africa. Mbabane: Swaziland Library and Information Association. 505-516. [Online[. https://www.scecsal.org/publications/papers2016/050_ndlangamandla_2016.pdf.

Nguyen, L.C. 2015. Establishing a participatory library model: a grounded theory study. The Journal of Academic Librarianship, 41(4): 475-87.

Ntaka, A. 2017. The use of social media sites by university library staff to facilitate undergraduate students. Master's thesis. Linnaeus University.

Ofili, D.N. and Emwanta M. 2014. Facebook as an information service delivery tool: perspectives of library staff at the University of Benin. African Journal of Library, Archiving and Information Science, 24(2): 195-202.

Onyaoku, E.N., Orakpor, A.M. and Ezejiofor, V.O. 2012. Knowledge and use of Web 2.0 by librarians in Anambra state, Nigeria. African Journal of Library, Archiving and Information Science, 22(1): 31-40. 
Padma, P. and Ramasamy, K. 2014. Literacy and use of social networking sites among research scholars and post graduate students of Madurai Kamaraj University, Madurai: an awareness study. International Journal of Information Dissemination and Technology, 4(1).

Penard, T., Poussing, N., Mukoko, B. \& Piaptie, G.B.T. 2015. Internet adoption and usage patterns in Africa: evidence from Cameroon. Technology in Society, 42: 71-80.

Pooja, M., Bhat, S. and Rao, M. 2019. Awareness, perception and use of social networking sites among library professionals and semi-professionals: a case study. Library Philosophy and Practice (e-journal). 2844. [Online]. https://digitalcommons.unl.edu/libphilprac/2844 (18 May 2020).

Rodgers, C.R. 2009. Social media, libraries, and Web 2.0: how American libraries are using new tools for public relations and to attract new users. German Library Association Annual Conference: Deutscher Bibliothekartag, Erfurt. 2-5 June. [Online]. https://dc.statelibrary.sc.gov/bitstream/handle/10827/6738/SCSL_Social_Media_Libraries_20095.pdf?sequence=1 (10 March 2016).

Rouse, M. 2011. What is social media marketing? [Online]. http://whatis.techtarget.com/definition/social-media-marketingSMM (28 September 2018).

Taylor \& Francis. 2014. Use of social media by the library: current practices and future opportunities. A white paper from Taylor \& Francis. [Online]. http://www.tandf.co.uk/journals/access/white-paper-Social-media.pdf (03 August 2017).

Tuten, T.L. 2008. Advertising 2.0: social media marketing in a Web 2.0 world. Santa Barbara: ABC-CLIO.

University of South Africa. 2012. UNISA policy on research ethics. Pretoria: University of South Africa.

Xie, I. and Stevenson, J. 2014. Social media application in digital libraries. Online Information Review, 38(4): 502-523. 